\title{
Aktive lag
}

\section{Bidrag til K\&K's diskussion om litteraturvidenskaben idag}

Ikke kun redaktionen, men også en del andre kunne konstatere, at »manglen på svar fra kvinderne er særlig iøjnefaldende « i $K \& K$ 's særnummer om litteraturvidenskaben idag. Hvor blev kvinderne af, da der skulle debatteres? Havde de barc for travlt til at svare? Satsede de på andrc sammenhange? Eller havde de slet ikke noget at sige?

Hvis nogle af de indbudte havde for travlt til at svare, skal jeg ikke fortænke dem i det. Vi har stillet krav om, at der skal flere kvinder ind i stillinger på universiteterne (og alle andre steder), at der skal værc kvinder i bedønmelsesudvalg, i forskningsråd og faglige landsudvalg, i censorkorps o.s.v. Da vi stadig ikke er så mange at tage af, er det lige så let at regne ud, som det er irriterende at måtte indrømme, at det somme tider kniber med at nå det hele. Det er jo i princippet en salig situation, at der er efterspørgsel efter os. Men rent konkret skal ens arbejdsevne være rimeligt højgearet for at kunne honorere kravene. Så enkelt er det.

Gunhild Agger er lektor ved Institut for Kommunikation, Aalborg Universitetscenter.

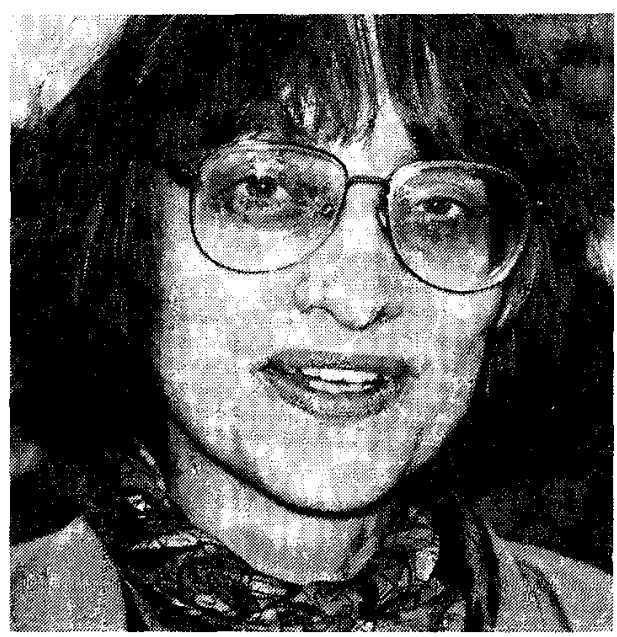


At nogle har satset på andre sammenhæenge, er heller ikke usandsynligt. Ambitionerne om at kvalificere den forskning, der går under betegnelsen »kvindeforskning «, har jo givet sig udslag i den ene skilsmisse efter den anden. Institutionel separatisme findes på ethvert dansk universitet $\mathrm{i}$ form af centre for kvindeforskning eller kvindestudier (se Eblebladets særnummer om Kvindestudier i Danmark, Århus 1990). De blev oprettet for at samle, styrke og synliggøre kvindeforskningen herhjemme. Det formål opfylder de også.

Men, for der er et men. Kvindestudiecentrene er blevet det øvrige forskersamfunds gode samvittighed. Kvindeforskningen har fået stillinger, penge, steder at være, og så behøver man i øvrigt ikke beskæftige sig ret meget med den. Nogle er lettede over at være sluppet af med massekommunikationsforskerne, så de bedre kan koncentrere sig om kvalitetsprodukter. Andre har det sikkert ligesådan, vil jeg insinuere, med kvindeforskerne. Når de er væk, behøver man ikke tænke så meget over kønnets betydning.

Hvem læser kvindeforskningens rcsultater - årbøger, tidsskrifter, arbejdspapirer, historier og forarbejder til litteraturhistorier? Det gør jo naturligvis især kvinder. Hvorfor det? Fordi denne forskning er henvendt til og beregnet på cn kvindelig målgruppe. Den forudsætter og er med til at oprctholde desintegrationen. Det kan være rimeligt nok og behageligt nok. Omkostningen er, at krasse konflikter og direkte dialoger udebliver. Ikke fordi samtale er umulig, men fordi den savner anledning.

Denne situation blev tydeligt markeret med $K \& K$ 's temanummer om litteraturvidenskaben idag. Nummeret er spændende, fordi det samler en række meget forskelligartede vurderinger og statusopgørelser. Trods kvindeforskningens selvvalgte separatisme virker nummeret samtidig som en provokation af den enkle grund, at der ingen kvinder er med. Når selv Poul Schlütcr øger kvindeandelen i sin regering, hvordan kan der så ske sådan noget blandt de intellektuclle? At sidde med det nummer $\mathrm{i}$ hånden var næsten som at se sig hensat til 1965. Næsten som om der var sat godt og grundigt punktum for de sidste 25 års debatter og studier.

Det var måske også meningen. Redaktørerne ville måske bare se, om der overhovedet var nogen, der opdagede det? Nogen, der gad reagere? Om pausesignalerne efter den selvstændige etableringsfase endelig kunne blive afløst af en diskussion igen?

Redaktørernes anden provokation ligger i deres forsøgsvise signalement af udviklingen som den ene modebølge efter den anden (og »feminismen« som en af dem). Er det signalement holdbart? Og var tavsheden udtryk for, at kvinderne ikke havde noget at sige? 
Jeg vil besvare begge spørgsmål benægtende.

Hvad iscencsacttclse og til en vis grad selvforståelse angår, er det rigtigt, at den enkelte teoribevægelse tenderer mod at proklamere sig selv som eksklusiv og hegemonisk, og at den enkelte forsker skal vare hurtig for at være trendy. Men der er også modgående tendenser, og selv om de fleste litteraturforskere ganske vist nok ønsker at »følge med «, er det vel ikke alle, der nødvendigvis til enhver tid har behov for at fremstå som repræsentanter for det sidste nye.

Når man overvejer, hvordan teoribevagelser forløber, melder metaforerne sig meget nemt. Og samtidig ringer også en alarm, der siger, at kombinationen af litteraturteori og metaforik måske ikke er så heldig. Den alarm har jeg haft indbygget siden jeg i 1971 læste Pil Dahlerups tankevakkende artikel »Om at bedrive metafor (Vindrosen 1, 1971). Ud fra en veloplagt gennemgang af forst og fremmest natur-, krigs- og personmetaforik i litteraturteori og tekstanalyse viser Pil Dahlerup, hvordan metaforerne gerne løber af med brugerne. Imperativet bliver så "Bedriv ikke metafor!«. Men det er lettere sagt end gjort. Sproget, også det teoretiske, er gennemtrængt af både døde og levende metaforer. Så måske skulle man omformulere imperativet til en opfordring til at vælge sine metaforer med omhu.

Den tendens, der på det individuelle plan imødegår den stadige udskiftning af dominerende teorier, kunne man kalde den arkcologiske bevidsthed. Eller den geologiske, hvis man foretrækker en naturmetafor, der konnoterer levende lag fremfor en kulturmetafor, der måske i højere grad konnoterer blotte aflejringer. Ligegyldigt hvilken af disse metaforer man vælger, vil jeg hævde at fænomenet gælder de fleste, der beskæftiger sig med litteraturteori. Nemlig det fænomen, at selv om der stadig tilføjes nye lag i ens individuelle teoridannelseshistorie, så bliver de gamle jo ikke inaktive af den grund. De kan blive omvurderet, beriget, revideret, kritiseret, set i ct nyt lys, men de vil manifestere sig alligevel, med vekslende styrke, vekslende grader af insisteren, men stadig som aktive lag. Måske mindre i den teoretiske diskurs end i den analytiske praksis.

Under alle omstændigheder gælder det de færreste, at de fuldstændig forkaster hele deres hidtidige grundlag, hver gang en ny teoridannelse dukker op. Man kan forholde sig tavst, registrcrende, eller aktivt, diskuterende og forarbejdende til disse besværlige processer. Men man kan dårligt bcklage, at der hele tiden er tale om netop processer, udvikling, dynamik. For hvad er alternativet?

En anden modgående tendens er på det idéhistoriske plan bevægclsernes modificerede genkomst. Jørgen Holmgaard diskuterer i »Historie 
i amcrikansk litteraturforskning « ( $K \& K 64)$, hvordan bevægelserne inden for de »toneangivende retninger $\mathrm{i}$ amerikansk og europæisk sammenhæng tilsyneladende krydser hinanden, således at en mere historisk og politisk orientcring nu afløser postmodernisme og dekonstruktivisme i USA, mens det omvendte har været tilfældet i Europa. Mønsteret har Søren Schou meget præcist formuleret, efter at have afvist diverse metaforer til at indfange fænomenet:

»Udviklingen præges af en både faktisk og erklæret afstandtagen fra det umiddelbart foregående som »inoperativt « - og af en tilegnelse af fjernere traditioner i modificeret form. $(K \& K 65-66$, p. 52).

Denne tendens har vi siden midten af 80 'erne kunnet se særlig markant i forbindelse med den samfundsmassigt og politisk orienterede kritik og i forbindelse med kvindeforskningen. Men hvis man ser begge disse teoribevagelser over et lidt længere spand af tid, er det også nemt at få øje på andre perioder end den umiddelbart foregående, hvor de - i en anden udformning - har været dynamiske.

Hvor en form for modificeret genkomst lader til at fungere på det tcorihistoriske niveau, mener jeg som sagt, at en arkæologisk/geologisk model i højere grad fungerer på det individuelle niveau. Hvis jeg skal illustrcre dette ud fra min egen litteraturteoretiske udvikling kan jeg nemlig lige så godt tilstå med det samme, at jeg mener at have lært noget af mange teoribevægelser, herunder de fleste af dem, som redaktørerne nævner i deres brev. Så er der selvfølgelig også adskilligt, som jeg har lagt fra mig igen. Og teorier, som har forekommet mig helt uantagelige.

Man fokuserer så ofte på bruddene, kritikken, opgøret. Men man kan jo også foretage den modsatte bevægelse og konstruere en positivliste eller, mindre halsbrækkende, give nogle eksempler på aktive lag i det teoretiske fclt.

Her kan jeg gerne begynde med nykritikken. Af nykritikken lærte jeg først og fremmest respekt for den enkelte tekst, årvågenhed over for lige pracis dens udsagn og måde at formulere sig på - kort sagt, jeg tilegnede mig dens centrale tekstanalyt iske begreber og tekstanalytiske praksis. Man behøver ikke diskutere længe med tekstanalyselærere fra min generation for at opdage, at nykritikken trods alle de barske opg $\phi$ r med den stadig fungerer sådan.

Et andet aktivt lag har jeg i en af nykritikkens tidlige inspirationskilder, den russiske formalisme. Propp gav mig den mest forståclige introduktion til strukturalismen, der findes, nemlig teorien om bestemte lovmæssigheder i fortællingens struktur, som han udvikler den i Eventyrets morfologi. En anden vigtig indsigt ligger i Tynjanovs og især Bachtins teori om det 
dialogiske princip i litteraturen og deres påvisning af, hvordan stil fungerer i denne sammenhæng. Stilisering, pastiche, parodi, skjult citering. Ordene som et slagsmål mellem forskellige synsvinkler og holdninger, signaleret gennem accentforskydninger, divergerende betoninger, forvrængninger. Hele det bachtinske teorikompleks om sproget, sådan som det på det seneste foreligger udformet især i The Dialogical Imagination fra 1981 det viser sig igen og igen at vere brugbart. Ikke kun i forbindelse med skønlitterære tekster, men også i forbindelse med f.eks. reklamer og dagligsprog - og i forbindelse med analyse af postmodernistiske fænomener, der jo elsker citatet $\mathrm{i}$ alle dets former.

Hvad så med marxismen? Det er lige før, det er et nyt tabuområde nu om stunder, omgærdet med tavshed og ruelse. Men marxisme har jo været samlebegreb for så meget, fra kapitallogik til idcologikritik, fra offentlighedsteori til »cultural studies . Og i hvert fald de to sidstnavnte sæetter, eksempelvis med Frankfurterskolen og Birminghamskolen nogle rammer for forståclse af forholdet mellem litteratur, udtryk, medier og samfund, som stadig er aktuelle for mig. Postmodernismen anfægter disse rammers gyldighed, men er dybt inspireret af en teoretiker som Walter Benjamin. Postmodernismen gør med god grund op med Adornos skarpe skcl mellcm avantgarden og det populacre, men den savner et kulturbegreb til at indfange de fine forskelle. Det har til gengæld Birminghamskolen.

Og så er der det historiske. Både i dens kapitallogiske og i dens ideologikritiske variant kunne marxismen føre til skematiske slutninger, analogisk afsind, blindhed over for det astetiske o.s.v. Alligevel mener jeg, at kravet om at inddrage det samfundsmæssige niveau skxrpede den historiske fornemmelse på en måde, som jeg ikke lige glemmer igen. Fornemmelsen for tid, sammenhange og sammenfald bidrog til klarlæegning og dybere forståelse af mange forhold i skaringspunktet mellem den »store« og den »lille « historie. Mentalitetshistorien betegner vel også en videreforelse af den type indsigter.

Hvor marxismen på en vis måde bevægede sig ud i konteksten, miljøet, samfundet, historien, der bevægede psykoanalysen sig den modsatte vej, ind i personerne og forfatterne og gav de txtte tolkninger på individ- og familicplan. Det er ikke sâ underligt, at marxismen og psykoanalysen gik så godt i spand sammen, for de supplerede hinanden fortræxfeligt. $\mathrm{Og}$ psykoanalysens indsigter? Dem har jeg da stadigvack liggende som fortolkningsmønstre, ikke til at undvare. - For slet ikke at tale om scmiotikkens indsigter og mange andre. Som sagt forsøger jeg ikke at give nogen udtømmende beskrivelse, men blot at fremdrage nogle eksempler 
på aktive lag.

Mit udgangspunkt for disse betragtninger var kvindeforskningen. Hvor bliver den nu af $i$ alt dette?

Inden for litteraturhistorien har kvinder ydet en respektabel grundforskningsindsats for at genopdage og genvurdere kvindelige forfatterskaber. Når det i højere grad er klarlagt, hvordan de udgrænsede kvindelige traditioner egentlig forholder sig til de dominerende mandlige, kommer den fælles litteraturhistorie naturligvis til at se anderledes ud. Historien om det moderne gennembrud i Danmark, f.eks., har forandret sig siden Pil Dahlerup har kortlagt det moderne gennembruds skrivende kvinder. Billedet af den nordiske realisme og naturalisme har fået nye facetter efter Jette Lundbo Levys bog om Victoria Benedictsson og Irene Engelstads om Amalie Skram.

Sideløbende og ofte i tæt interaktion med dette grundforskningsarbejde har en række principielle spørgsmål af teoretisk karakter udkrystalliseret sig. Spørgsmål som: Var det med rette eller urette så mange kvindclige forfaltere blev bortgemt? Var deres produktion kun historisk og bevidsthedshistorisk interessant? Var den underlegen ud fra en xstetisk målestok? Og i tilknytning hertil: Findes der en kvindelig æstetik? En kvindelig kreativitet? Og sammenhængende med dette: Er der særlige mctoder, der trænger sig på i studiet af kvinders udtryksformer?

Disse spørgsmål er langtfra afklarede, men de er naturligvis af stor betydning for den almene debat om litteraturvidenskab i dag. $O g$ konturerne af nogle svar eksisterer da også.

Ud fra vidt forskellige metodiske og teoretiske indfaldsvinkler er der i de senere år forctaget en række studier i kvindelitteratur, som alle har det til fælles, at de bidrager til at udfolde begrebet om, hvad et kvindeperspektiv indebærer og dermed rejser det overordnede spørgsmål om, hvad kønnet egentlig betyder. Mange af dem har interesse også i en litteraturteoretisk sammenhæng. For blot at nævne nogle få:

Jette Lundby Levy arbejdede i sin bog om Victoria Benedictsson med dobbeltblikket som analysekatcgori til at klarlægge en central tematisk og stilistisk ambivalens. Oplevelsen af at være set og at se, både indefra og udefra, var (er?) fundamental i en kvindelig sammenhæng. Begrebet om dobbeltblikket, der egentlig stammer fra dels Lacan, dels Laerman og Schneider, har da også vist sig velegnet $\mathrm{i}$ andre sammenhænge, således har f.eks. Karen Klitgaard Povlsen brugt det i sin bog om kvindexstetik og ugeblade, Blikfang.

Inger-Lise Hjordt-Vetlesen giver $\mathrm{i}$ sin bog om Helene Strange en analyse af blokeringerne og begrænsningerne hos Helene Strange - og 
dermed et signalement af den autodidakte kvindelige forfatters dilemmaer - og muligvis også en forklaring på hendes publikumsappel hos det samtidige kvindelige publikum. Dette er et interessant bidrag til diskussionen om dels det kvindeæstetiske, dels spørgsmålet om litterær kvalitet.

Merete Stistrup søger i sin bog om Kvindesprog at indkredse særlige kendetegn ved kvinders sprogbrug og diskuterer $\mathrm{i}$ den forbindelse en række distinktive træk. Men er det rigtigt, at vi har et særligt forhold til sproget, at vi foretrækker det orale, etc? Kan man overhovedet diskutere skriveprocesser i kønstermer? Metaforerne kunne tyde på det - også de mandlige. Igen et interessant bidrag til en fælles diskussion.

Dct kan godt ske, at nogle mener, at sådan nogle spørgsmål er uddebatterede. Selv mener jeg det ikke. Tværtimod synes jeg kønsperspektivet gang på gang viser sig at være et væsentligt lag i den store dialog om litteratur og teori.

Kort sagt, jeg trakker i enhver analyse- og fortolkningssituation på alle de aktive lag i min teoretiske bevidsthed. Hvilke, der særligt bliver foretagsomme, afhænger naturligvis af det materiale, der skal analyseres og fortolkes. Lagene er afhængige af teorihistorien, de er blevet til i forbindelse med den. De er ikke ufølsomme over for tidsåndens krav, d.v.s. hvad der pludseligt og ind imellem tilsyneladende arbitrært er blevel »inoperationelt «. På den anden side er de hellcr ikke restløst underlagt tidsåndens krav. De er jo også et resultat af mine egne valg, både blandt de gamle lag og blandt de nye.

Det eneste, en sådan holdning afskærer én fra, er at have ambitioner om at finde den finale teori eller at stå som repræesentant for den seneste, fikseste og mest toneangivende retning. 